\title{
Effects of Oxytetracycline Antibiotic on GST Enzyme Activity and Gene Expression Levels in Rainbow Trout
}

\author{
Abdulkadir Çiltaş, Yusuf Zekeriya Balık
}

\begin{abstract}
In this study, effects of oxytetracycline on glutathione s-transferase enzyme activity and gene expression levels in rainbow trout (Oncorhynchus mykiss) liver were investigated. For this purpose, liver tissues from rainbow trout exposed to oxytetracycline application were collected at third, sixth and 12th hours. The group not exposed to oxytetracycline was assigned as control. While the lowest enzyme activity of GST was at 12th, the highest enzyme activity was observed in control. While compared with the control group, enzyme activity at 12th hour was highly significant $(\mathrm{p}<0.001)$, the third and sixth hours groups were significant $(p<0.05)$. The lowest gene expression level was found in 12th group and the highest level was the third. While compared with the control group, difference at the third hour of gene expression level was highly significant $(p<0.001)$, at the sixth and 12 th hours groups was not significant. As a result, there was understand that no correlation between gene expression levels and GST enzyme activity.
\end{abstract}

Keywords - Oncorhynchus mykiss, Liver, Glutation $S$ Transferase, Oxytetracycline, Enzyme Activity.

\section{Introduction}

Antibiotics have been used in fish health care more than 50 years. The use of tetracyclines toward to gram negative pathogenics in trout culture is an old technics [1]. Oxytetracycline is the first antibiotic which is approved by FDA [2]. It has been reported that oxytetracyclines were approved to wide using to threathments of bacterial fish diseases in many countries such as Norway, Italy and Japan $[3,4,5,6,7]$

Glutation S-Transferase (GST) (EC.2.5.1.18) is very much functional enzyme because of generating homeosthasis [8]. GST exists in many organisms like mammalian, insects, fish, birds and microorganisms. The most GST founding tissues are cytosoles and membranes of many organs such as liver, intestine, rena [9]. This enzyme has been categorized as GSTP1, GSTM1 and GSTT1 according to its biochemical, immunological and structural characteristics. The GSTs are tissue specific expressed enzymes $[10,11]$, and has many substrates. GST eliminates food based toxics. Isomerization of prostaglandin transfers nonsubstrate ligands such as hem, bilirubin, bile salts and fatty acids by bounding with GSH [12].

The research aimed to clarify effects of oxytetracycline on GST expression and also enzyme activity.

Abdulkadir Çiltaş, Yusuf Zekeriya Balık

Atatürk University, Faculty of Agriculture, Department of Agricultural Biotechnology

Turkey

\section{Material and Methods}

\section{A. Chemicals}

Oxytetracycline were obtained from BAYER (Leverkusen, Germany). All of the other chemicals used for analytical grade were purchased from Merck (Darmstadt, Germany)

\section{B. Fish Husbandry and Maintenance}

A total of 28 rainbow trout (Onchorynchus mykiss Walbaum) were used for this experiment. The fish were provided from Ataturk University, Fisheries Faculty. All fish were one-year-old, and its main weight was $230 \pm 20 \mathrm{~g}$. The trout were kept cylindrical tanks in freshwater with water flow of $1.5 \mathrm{~L} / \mathrm{min}, 10 \pm 1^{\circ} \mathrm{C}$ average water temperature, 9 ppm dissolved oxygen, $\mathrm{pH} 7.6 \pm 0.2$, total hardness was 102 mg $\mathrm{CaCO}_{3}$ with natural dark/light cycle. The fish were fed twice a day with a commercial trout diet (Sürsan AquaMax, Sürsan inc.). All fish were starved two days before antibiotic administration. Fish treatments were conducted according to Applied Research Ethics National Association (2002)

\section{Experimental Design}

The fish were randomly divided into two groups. Group 1 was the control $(n=7)$, and group 2 was orally oxytetracycline administrated for $100 \mathrm{mg} / \mathrm{kg}$ body weight $(\mathrm{n}=21)$. After antibiotic administration, 7 fish were killed at $3^{\text {rd }}, 6^{\text {th }}$ and $12^{\text {th }}$ hours, and liver tissue samples were collected, washed with ice-cold saline two times and immediately transferred in liquid nitrogen and stored at $80^{\circ} \mathrm{C}$.

\section{GST Enzyme Activity Determination}

Liver tissues homogenized in a homogenizer, in $50 \mathrm{mM}$ Tris/HCl buffer, pH 7.6, containing $1 \mathrm{mM}$ DTT, $1 \mathrm{mM}$ EDTA and $1 \mathrm{mM}$ PMSF of $1 / 5(\mathrm{w} / \mathrm{v})$. Homogenate was centrifuged at $10000 \mathrm{rpm}$ for $30 \mathrm{~min}$ and supernatant was used for enzymatic activity determination. All steps were performed in $+4^{\circ} \mathrm{C}$. GST (EC.2.5.1.18) enzyme activity was determined as described by Habig et al. (1974). One unit conjugates $1.0 \square \mathrm{mol}$ of 1-chloro-2,4-dinitrobenzene with reduced glutathione per $\mathrm{min}$ at $\mathrm{pH} 6.5$ at $25^{\circ} \mathrm{C}$. In a $1 \mathrm{ml}$ reaction mix, final concentrations are $20 \mathrm{mM} \mathrm{K}$-Phosphate, $0.68 \mathrm{mM}$ EDTA, pH: 7.6, $2 \mathrm{mM}$ GSH and $2.5 \mathrm{mM}$ CDNB. Protein concentrations in the supernatants were determined using the Bradford assay with bovine serum albumin as the standard (13). 
Proc. of The Fifth Intl. Conf. On Advances in Applied Science and Environmental Technology - ASET 2016 Copyright $($ Institute of Research Engineers and Doctors, USA .All rights reserved.

ISBN: 978-1-63248-106-1 doi: 10.15224/ 978-1-63248-106-1-32

\section{E. RNA isolation and cDNA synthesis}

Total RNA was isolated from $50 \mathrm{mg}$ frozen muscle, liver and kidney tissues with a RNeasy Lipid Tissue Mini Kit (Qiagen, cat. no. 74804) using the Qiacube robot (Qiagen, Hilden, Germany). RNA was treated with DNase I in order to avoid genomic contamination. RNA concentrations and quality were verified by means of nanodrop spectrophotometer $\left(\mu\right.$ Drop $^{\mathrm{TM}}$ Plate, Thermo Scientific, cat. no. 12391) and RNA gel electrophoresis, respectively. Following isolation, cDNA synthesis was performed using the ThermoScript ${ }^{\mathrm{TM}}$ RT-PCR System for First-Strand cDNA Synthesis Kit (Invitrogen, cat. no. 11146-016) according to the manufacturer's protocol. All cDNA was stored at -20 ${ }^{\circ} \mathrm{C}$ until use.

\section{F. TaqMan probe and primer design}

Primers and TaqMan probes were designed in Primer3 software (www.bioinfo.ut.ee/primer3), checked by PrimerBLAST software and purchased from Metabion International (Martinsried, Germany). $\beta$-Actin was used as reference gene, since it was not affected by any of the treatments. In order to perform Real Time PCR, TaqMan probe of the target and reference gene were conjugated with FAM/TAMRA and CY5/BQ2 respectively. The primer and probe sequences, amplification length and genbank accession number for real-time PCR are provided in Table 1.

\section{G. Quantitative real time PCR}

Quantification of gene expression by real-time PCR analysis was performed using a thermal cycler Qiagen Rotor-Gene. The real-time PCR was carried out in a reaction volume of $50 \mu$ containing template DNA, $900 \mathrm{nM}$ of both target and reference forward and reverse primers, $250 \mathrm{nM}$ both target and reference TaqMan probes, and $25 \mu \mathrm{l}$ FastStart TaqMan Probe Master (Applied Biosystems) which consists of AmpliTaq Gold DNA Polymerase, AmpErase uracil N-glycosylase (UNG), dNTP with dUTP, and optimized buffer component. The amplification and detection of the samples and the standards were performed using the following thermal cycling conditions: $50{ }^{\circ} \mathrm{C}$ for 2 min for activation of optical AmpErase UNG enzyme, $95^{\circ} \mathrm{C}$ for $10 \mathrm{~min}$ as hot start to activate AmpliTaq Gold DNA polymerase followed by 45 cycles of denaturation at $95^{\circ} \mathrm{C}$

TABLE I. THE PRIMER AND PROBE SEQUENCES, AMPLIFICATION LENGTH AND GENBANK ACCESSION NUMBER

\begin{tabular}{|c|c|c|c|c|}
\hline Gene & \begin{tabular}{|c} 
Primer and \\
Probe
\end{tabular} & Sequence & $\begin{array}{l}\text { Len. } \\
\text { (bp) }\end{array}$ & $\begin{array}{l}\text { Acc. } \\
\text { Num. }\end{array}$ \\
\hline \multirow{3}{*}{$\breve{U}$} & Forward & TGGCTGACGTTATTGTCTTCC & \multirow{3}{*}{112} & \multirow{3}{*}{ 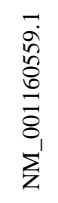 } \\
\hline & Reverse & CTGGGTCTGTCCTTCACCATA & & \\
\hline & Prob & ${ }^{\text {FAM_CGGCGCGTTACCCCAAACTG-AMRA }}$ & & \\
\hline \multirow{3}{*}{. } & Forward. & TGGCCGTACCACCGGTAT & \multirow{3}{*}{79} & \multirow{3}{*}{ 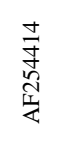 } \\
\hline & Reverse & GCAGAGCGTAGTCCTCGTAGATG & & \\
\hline & Prob & ${ }^{\mathrm{Cy} 5}$ - CTCCGGTGACGGCGTGACCC $-{ }^{\mathrm{BQ} 2}$ & & \\
\hline
\end{tabular}

for $15 \mathrm{~s}$, and annealing and extension at $60{ }^{\circ} \mathrm{C}$ for $1 \mathrm{~min}$. Real-Time PCR data were analysed using the efficiency $(\mathrm{e})^{(-\Delta \mathrm{Ct})}$ method, which is used to determine mRNA levels in gene expression against control group and housekeeping genes ( $\beta$-Actin). Analytical sensitivity was confirmed by running standard curves. Amplification efficiency (e) was calculated based on the slopes of the curves (slope) using the formula $\mathrm{e}=10^{(-1 / \text { slope })}[14]$, and the slope value via RotorGene software.

\section{H. Statistical analyses}

All experiments were triplicated. One-way ANOVA and Duncan's multiple range test (SPSS 22.0) was used to determine the effects of oxytetracycline. P-values below 0.05 were considered statistically significant.

\section{Results and discussion}

While GST activity of control group was $12.8 \pm 0.6$ $\mathrm{EU} / \mathrm{mg}$, those of oxytetracycline treated groups at 3,6 and $12 \mathrm{~h}$ were found as respectively $10.5 \pm 0.7 \mathrm{EU} / \mathrm{mg}, 11.2 \pm 0.5$ EU/mg, 9.5 $\pm 1.1 \mathrm{EU} / \mathrm{mg}$. The lowest enzyme activity was 12 $\mathrm{h}$ group, and the highest one was the control. Compared with control, the $12 \mathrm{~h}$ group had extremely significant $(\mathrm{p}<0.001)$, the $6 \mathrm{~h}$ and the $3 \mathrm{~h}$ group had significant decrease $(\mathrm{p}<0.05)$. When the experimental groups were compared, differences between the sixth and third hours to 12 hours were found statistically significant $(\mathrm{p}<0.05)$, but the difference between three and six hours were not significant (Table 2).

GST plays a primary role in detoxification of different chemicals and endogenously derives reactive compounds [15]. Many endogenous GST substrates are formed as a consequence of modification of macromolecules by reactive oxygen species, and the transferases are therefore considered to serve an antioxidant function $[16,17]$. GST catalyzes the conjugation of reduced glutathione (GSH) [18, 19]. Additionally several GST isoenzymes exhibit other GSHdependent catalytic activities including the reduction of organic hydroperoxides [20] and isomerization of various unsaturated compounds [21, 22, 23].

It is reported that, in both liver and pancreas, the higher dose of tetracycline $(200 \mathrm{mg} / \mathrm{kg})$, caused significant decrease in GST activity. [24]. Depending on the degree of oxidative stress and resulting tissue damage, the antioxidant enzyme levels progressively decrease [25].

After oral administration of oxytetracycline from the third hour to the next, serum oxytetracycline concentration reaches peak level [26]. As can be seen in Figure 1, from the third hour after the oxytetracycline application, GST activity level has decreased. This is thought to cause intense deplete $\mathrm{GSH}$ in the liver.

TABLE II. GST ENZYME ACTIVITIES

\begin{tabular}{|l|c|}
\hline Group & Specific Enzyme Activity (EU/mg) \\
\hline Control & $12,8 \pm 0,6^{\mathrm{a}}$ \\
\hline 3h & $10,5 \pm 0,7^{\mathrm{bc}}$ \\
\hline 6h & $11,2 \pm 0,5^{\mathrm{bc}}$ \\
\hline $\mathbf{1 2 h}$ & $9,5 \pm 1,1^{\mathrm{c}}$ \\
\hline
\end{tabular}

The average for each parameter are marked with different letters to indicate groups that are different from each other, $\mathrm{p}<0.05, \mathrm{n}=7$ 
Proc. of The Fifth Intl. Conf. On Advances in Applied Science and Environmental Technology - ASET 2016 Copyright (C) Institute of Research Engineers and Doctors, USA .All rights reserved.

ISBN: 978-1-63248-106-1 doi: 10.15224/ 978-1-63248-106-1-32

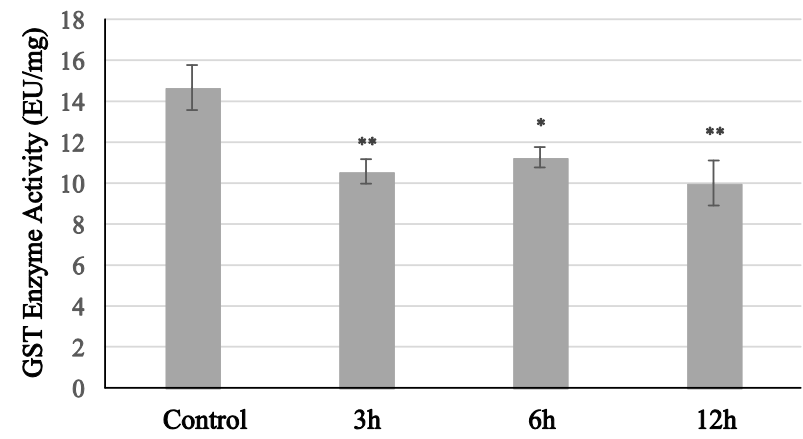

Figure 1. Comparison for GST enzyme activities of control and treatment groups.

GST gene expression levels of Oxytetracycline administrated groups ( $3 \mathrm{~h}, 6 \mathrm{~h}$ and $12 \mathrm{~h})$ were respectively $11.6 \pm 2.3 \mathrm{ng} / \mathrm{ml}, 2.4 \pm 1.7 \mathrm{ng} / \mathrm{ml}, 2.3 \pm 1.5 \mathrm{ng} / \mathrm{ml}$ (Table 3.). The highest expression level among experimental groups was $12 \mathrm{~h}$, and the lowest was $3 \mathrm{~h}$. Compared with control group there was extremely significant increase at $3 \mathrm{~h}$ group $(p<0.001)$, and differences of others were not significant.

As seen in Figure 2, at the third hour oxytetracycline reached peak serum levels, and GST gene expression has reached the highest level. After this stage, the expression level was down to normal level, because serum peak level time of oxytetracycline is at the $3-\mathrm{h}$, and half-life of it is at the 12-h [26].

There is no report about effect of oxytetracycline on GST gene expression, but relationship between several substance and GST gene expression are available.

Increased liver GST mRNA expression level in Coho salmon (Oncorhynchus kisutch), which exposed to cadmium and tilapia (Oreochromis niloticus), which exposed to cylindrospermopsin, were reported [27, 28]. Similar to these results, after oxytetracycline administration, GST gene expression value increased synchronously serum oxytetracycline level (Figure 2).

\section{TABLE III. GST GENE EXPRESSION LEVELS RELATIVE TO $\beta$ ACTIN}

\begin{tabular}{|l|c|}
\hline & Gen expression level \\
\hline Control & $1 \pm 0^{\mathrm{b}}$ \\
\hline $\mathbf{3 h}$ & $11,635 \pm 2,30^{\mathrm{a}}$ \\
\hline $\mathbf{6 h}$ & $2,460 \pm 1,77^{\mathrm{b}}$ \\
\hline $\mathbf{1 2 h}$ & $2,321 \pm 1,50^{\mathrm{b}}$ \\
\hline
\end{tabular}

The average for each parameter are marked with different letters to indicate groups that are different

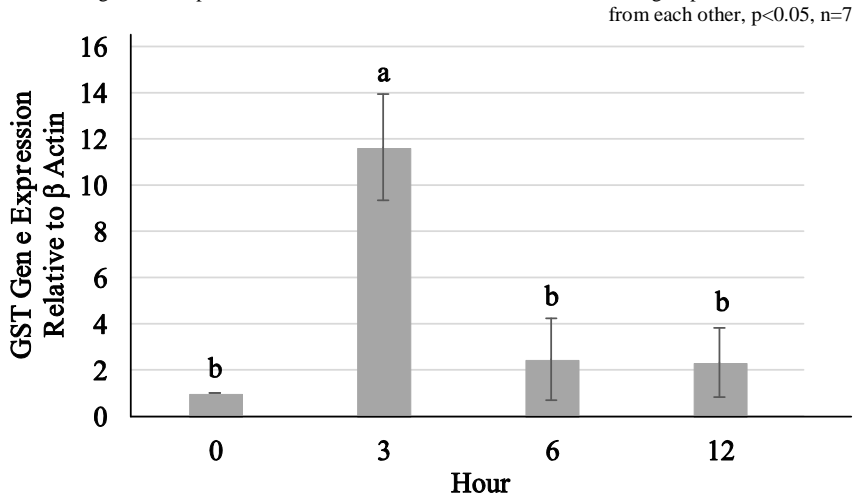

Figure 2. GST mRNA levels of oxytetracycline treated trout liver tissue at different times.
Different authors reported that there was no correlation between mRNA level and enzyme activity [29, 30, 31]. We also found similar results compatible with previous reports.

Oxytetracycline stimulated GST gene expression at the $3 \mathrm{~h}$ period, which is the peak serum concentration. In subsequent hours, expression levels of GST genes decreased. It was considered that this originated from lowering in GST enzyme activity depending on excessive GSH consumption.

This study showed that oxytetracycline administration induced oxidative stress by reducing GST enzyme activity in liver. But there was no correlation between GST enzyme activity and gene expression level.

\section{Acknowledgment}

This work was supported by Ataturk University Scientific Research Projects Coordination Commission (ATAUNI-BAP) with project number 2015/150.

\section{References}

[1] V. Inglis, "Antibacterial chemotherapy in aquaculture: review of practice, associated risks and need for action," Iloilo, Philippines. Iloilo, Philippines, Aquaculture Department, Southeast Asian Fisheries Development Center. pp. 7-22. 2000 [SEAFDEC/FAO/CIDA meeting 63 on the use of chemicals in aquaculture in Asia, 20-22 May 1996]

[2] L.A. Reed, T.C. Siewicki, J.C. Shah, "Pharmacokinetics of oxytetracycline in the white shrimp", Litopenaeus setiferus. Aquaculture, 232, pp. 11-28. 2004.

[3] H.V. Björklund, "Oxytetracycline and oxolinic acid as antibacterials in aquaculture-analysis, Pharmacokinetics and environmental impacts," Academic Disertation. Department of Biology Abo Akademi Universsity. Abo, Finland. pp. 1-4, 1991.

[4] D. Akșit, C. Kum, "Gökkușağı Alabalıkları (Oncorhynchus mykiss, Walbaum 1792)'nda sık görülen patojen mikroorganizmaların tespiti ve antibiyotik duyarlılık düzeylerinin belirlenmesi," YYÜ Veteriner Fakakülte Dergisi 19 vol. 1, pp. 1-7, 2008.

[5] J. Malvisi, G.D. Rocca, P. Anfossi, and G. Giorgetti, "Tissue distribution and residue depletion of oxytetracycline in sea bream (Sparus aurata) and sea bass (Dicentrarchus labrax) oral administration," Aquaculture, 147 pp. 159-168, 1996.

[6] F. Balta, R. Serezli, Ş. Kayış, S. Akhan, ve İ. Yandı, "Gökkuşağı Alabalığında (Oncorhynchus mykiss) oksitetrasiklin HCl'nin nötrofillerin fagositik aktivitesine ve bazı kan parametrelerine etkisi," Süleyman Demirel Üniversitesi Eğirdir Su Ürünleri Fakültesi Dergisi, 1, pp. 7-11, 2005.

[7] P. Smith, "Is sediment deposition the dominant fate of oxytetracycline used in marine salmonid farms: a review of available evidence," Aquacult. 146, pp. 157-69, 1996.

[8] F. Arı, E. Dere, "Benzen'in karaciğer glutatyon s-transferaz enzim aktivitesine in vitro etkisi," Fen Bilimleri Dergisi, 24, vol. 1, pp. 7681, 2003.

[9] H. W. Habig, J. M. Pabst, W. B. Jakoby, J. "Glutathione Stransferases. The first enzymatic step in mercapturic acid formation," J. Biol. Chem., 249 vol. 22, pp. 7130-7139, 1974.

[10] K. Berhane, M. Widersten, A. Engstrom, J. W. Kozarich, and B. Mannervik, "Detoxication of base propenals and other alpha, betaunsaturated aldehyde products of radical reactions and lipid peroxidation by human glutathione transferases," Proc. Natl. Acad. Sci. U.S.A, 91, vol. 4, pp. 1480-1484, 1994.

[11] P. Karagianni, D. Rallis, L. Fidani, M. Porpodi, K.Kalinderi, C. Tsakalidis, and N. Nikolaidis, "Glutathion-S-Transferase P1 polymorphisms association with broncopulmonary dysplasia in preterm infants," Hippokratia, 17, vol. 4, pp. 363-367, 2013.

[12] T.D. Boyer, "The glutathione s-transferases: an update hepatology," 9 , vol. 3, pp. 486-96, 1989. 
[13] M. M. Bradford, "A rapid and sensitive method for the quantitation of microgram quantities of protein utilizing the principle of protein-dye binding," Analytical Biochemistry, 72, pp. 248-251, 1976.

[14] M.W. Pfaffl, “A new mathematical model for relative quantification in real-time RT-PCR,” Nucleic Acids Res., 9, vol. 29, pp. 2003-2007, 2001.

[15] J.D. Hayes and D.J. Pulford, "The glutathione S-transferase supergene family: regulation of GST and the contribution of the isoenzymes to cancer chemoprotection and drug resistance," Critical Reviews in Biochemistry and Molecular Biology, 30, pp. 445-600, 1995.

[16] J.D. Hayes and L.I. McLellan, "Glutathione and glutathionedependent enzymes represent a co-ordinately regulated defence against oxidative stress," Free Radical Research, 31, pp. 273-300, 1999.

[17] B. Mannervik, "Glutathione and the evolution of enzymes for detoxication of products of oxygen metabolism," Chemica. Scripta, 263, pp. 281-284, 1986.

[18] L.F. Chasseaud, "The role of glutathione and glutathione Stransferases in the metabolism of chemical carcinogens and other electrophilic agents," Advances in Cancer Research, 29, pp. 175-274, 1979.

[19] B. Mannervik, "The isoenzymes of glutathione transferase," Advances in Enzymology and Related Areas of Molecular Biology 57, pp. 357-417, 1985.

[20] B. Ketterer, D.J. Meyer, J.B. Taylor, S. Pemble, B. Coles and G. Fraser, "GSTs and protection against oxidative stress". In Glutathione S-Transferases and Drug Resistance, J.D, Hayes T.J. Mantle and C.B. Pickett (eds), Taylor and Francis, Bristol, pp. 1990, 97-109.

[21] A.M. Benson, P. Talalay, J.H. Keen and W.B. Jakoby "Relationship between the soluble glutathione-dependent A5-3-ketosteroid isomerase and the glutathione S-transferases of the liver," Proceedings of the National Academy of Sciences, USA, 74, pp. 158-162. 1977.

[22] V. Adler, Z. Yin, S.Y. Fuchs, M. Benezra, L. Rosario, K.D. Tew, M.R. Pincus, M. Sardana, C.J. Henderson, C.R. Wolf, R.J. Davis and Z. Ronai, "Regulation of JNK signaling by GSTp," The EMBO Journal, 18, pp. 1321-1334. 1999,

[23] S.G. Cho, Y.H. Lee, H.S. Park, K. Ryoo, K.W. Kang, J. Park, S.J. Eom, M.J. Kim, T.S. Chang, S.Y. Choi, J. Shim, Y. Kim, M.S. Dong, M.J. Lee, S.G. Kim, H. Ichijo and E.J. Choi, "Glutathione Stransferase $\mathrm{Mu}$ modulates the stress-activated signals by suppressing apoptosis signal- regulating kinase 1," The Journal of Biological Chemistry 276, pp. 12749-12755, 2001.

[24] K.K. Asha, T.V. Sankar and P.G. Nair, Effect of tetracycline on pancreas and liver function of adult male albino rats. Journal of Pharmacy and Pharmacology, 59(9), 1241-1248. 2007.

[25] M.F. Hill and P. K. Singal, "Antioxidant and oxidative stress changes during heart failure subsequent to myocardial infarction in rats," Am. J. Pathol. 148, pp. 291-300, 1996.

[26] R. Özaras, F. Tabak, R. Öztürk, “Antibiyotikler” III. İ.Ü. Cerrahpaşa Tıp Fakültesi Sürekli Tıp Eğitimi Etkinlikleri. Akılcı Antibiyotik Kullanımı ve Erişkinde Toplumdan Edinilmiş Enfeksiyonlar. Sempozyum Dizisi, pp. 55-82, 2002.

[27] H. M. Espinoza, C. R. Williams and E. P. Gallagher, Effect of cadmium on glutathione S-transferase and metallothionein gene expression in coho salmon liver, gill and olfactory tissues. Aquatic Toxicology (Amsterdam, Netherlands), 110-111, 37-44. 2012.

[28] D. Gutiérrez-Praena, A. Jos, S. Pichardo, M. Puerto, and A. M. Cameán, "Influence of the exposure way and the time of sacrifice on the effects induced by a single dose of pure Cylindrospermopsin on the activity and transcription of glutathione peroxidase and glutathione-S-transferase enzymes in Tilapia (Oreochromis niloticus)," Chemosphere, 90 vol. 3, pp 986-992, 2013.

[29] P.A. Olsvik, T. Kristensen, R. Waagb $\varnothing$, B.O. Rosseland, K.E. Tollefsen, G. Baeverfjord and M.H. Berntssen, mRNA expression of antioxidant enzymes (SOD, CAT and GSH-Px) and lipid peroxidative stress in liver of Atlantic salmon (Salmo salar) exposed to hyperoxic water during smoltification. Comp. Biochem. Phys. C 141, pp. 314 323. 2005.

[30] P.M. Craig, C.M. Wood and G.B. McClelland, "Oxidative stress response and gene expression with acute copper exposure in zebrafish (Danio rerio)," Am. J. Physiol. Regul. Integr. Compar. Physiol. 293, pp. 1882-1892, 2007.

[31] Y. Jin, X. Zhang, L. Shu, L. Chen, L. Sun, H. Qian, and Z. Fu, "Oxidative stress response and gene expression with atrazine exposure in adult female zebrafish (Danio rerio)," Chemosphere, 78 vol. 7 , pp. 846-852, 2010.

About Author (s):

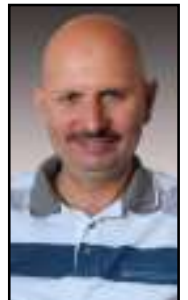

Dr. Abdulkadir Çiltaş

$\mathrm{He}$ is working in Ataturk University, Faculty of Agriculture, Department of Agricultural

Biotechnology. He works about enzyme purification, characterization, enzyme and drug relationship and 